\title{
Tobacco, alcohol, drugs consumption, and perception about the family functioning among adolescents in Tuzla Canton
}

\author{
Maida Mulićn, Vesna Ferković , Azra Kurtić3, Ivana Ferković Pašićc \\ ${ }^{1}$ Institute of Public Health of Tuzla Canton, Tuzla, Bosnia and Herzegovina, ${ }^{2}$ Department of Social Medicine, Medical School, \\ University of Tuzla, Bosnia and Herzegovina, ${ }^{3}$ Department of Psychology of Communication, Medical School, University of \\ Tuzla, Bosnia and Herzegovina, 'Department of Journalism, Faculty of Humanities and Social Sciences, University of Tuzla, \\ Bosnia and Herzegovina
}

\begin{abstract}
Introduction: Family is a strong communicative base of adolescent development, even though environment has its own influence as well. The study links the risks and substance use (tobacco, alcohol, and drugs) among adolescents to their perception about the functioning of family. Hence, a model of functional communication has been established aimed at preventing the defined problem.
\end{abstract}

Methods: A random, voluntary, and anonymous survey was conducted that included a non-clinical sample of 1.018 adolescents in the Tuzla Canton. In a prospective method, the Youth Risk Behavior Surveillance System of the World Health Organization (WHO) was used, modified for this study.

Results: The average prevalence of substance use is $81.2 \%$ and is significant for male adolescents. Some $33 \%$ of the respondents smoke tobacco, $25.4 \%$ drinks alcohol, while $12 \%$ of the surveyed adolescents use drugs. There is a significant correlation between a complete and broader family and tobacco and alcohol use, while incomplete family and household without family members are linked to tobacco use only. The risk of alcohol use is significantly related to father's higher level of education while mother's high school education is significantly related to tobacco and alcohol use. As perceived by adolescents, parents have negative attitudes about substance use (75\%), they are more strict in setting the rules of behavior at home $(45.5 \%)$ than outside, and control where more than with whom adolescents spend their free time ( $F=14.14, \mathrm{df}[2.6], p<0.05)$.

Conclusion: The functioning of a family (family structure, parents' education, and the quality of communication in a family) is a significant factor in the context of tobacco, alcohol, and drug use.

Key words: Prevalence of tobacco; alcohol; drugs; family; adolescents; communicative model of behavior

\footnotetext{
*Corresponding author: Mulić Maida,

Tuzlanskog odreda No 6, 75000 Tuzla,

Bosnia and Herzegovina.

Phone: +38762843699.

E-mail: maida.mulic@zjztk.ba
}

Submitted: 20 October 2017/Accepted: 16 November 2017

DOI: https://doi.org/10.17532/jhsci.2017.462

UNIVERSITY OF SARAJEVO FACULTY OF HEALTH STUDIES

\section{INTRODUCTION}

Primary family socialization is a strong communication base of adolescent development although peers and environment have their own effects in secondary socialization (1). The functioning of a family prevents and protects against various types of addiction $(2,3)$. At the same time, promotion 
of the functioning of a family may reduce negative outcomes $(4,5)$. Therefore, the complexity of family relations and risky behavior of adolescents as well as their assimilation in the environment, pursuant to family functioning, are measured by the following indicators: Inclusion of parents, positive parenthood, and communication between parents and adolescents (6). Schwartz et al. (7) supported many studies on joint cultural causes in a family and adolescent risky behavior with drug and alcohol use $(8,9)$. Labrie et al. (10) indicated a decrease in alcohol use among children in comparison to previous studies $(11,12)$ and a significant influence of parent communication on late adolescent period (13-15), while the lack of communication in a family is related to alcohol usage.

The assessment of adolescent perception about their parents revealed that only the perceived assimilation gap has a negative influence on adolescent behavior and addiction abuse $(16,17)$. However, Unger et al. (18) reported about Latin American adolescent having a lower risk of tobacco and marijuana use but not alcohol, which they relate to the cultural and family norms related to alcohol. The recent study of Cano et al. (19) supports the previous studies on Latin American gender norms related to alcohol use and cultural identity $(7,20)$. For example, the term "machismo" is considered to contribute to adolescent behavior, including alcohol use $(21,22)$. At the same time, the results point to the strategy of parent and adolescent education aimed at achieving communication and maintaining family cohesion despite cultural differences.

For example, assimilation mediated the effect of immigrant generation on behavior and alcohol use for Mexican adolescents while for Cuban adolescents financial situation in a family is a risk factor of alcohol addiction (23).

In the context of communication between parents and adolescents, functional family is characterized by warm and close relations enabling adolescents to be open and parents to constantly guide adolescents in the process of value acquisition as a protective factor against addiction. The results of a study in Southern California indicate the benefits of the functioning of a family for psychological well-being through the promotion of family and responsibility for boy and girls and the promotion of traditional gender roles for girls (24). La Framboise and Rowe (25) underlined bicultural skill training of parents and children of both sexes. Lorenzo-Blanco et al. (26) reported about Latin American boys showing the feeling of stronger discrimination than girls, and in their holistic approach, they indicate that Latin American boys start smoking at an earlier age without the perceived security at the school and social support (27). Similar gender experiences in communicates are reported by other studies of this problem, which confirm diverse constellation of experience among girls $(28,29)$.

Parental supervision over adolescents has an intermediate effect on peer influence (30), and parents' knowledge about the adolescent use of alcohol is related to the selection of peers and indirectly to alcohol use. Previous studies report that through parental influence (for example, communication, acceptance of alcohol use and parental supervision) adolescent may be sensitive to the influence of their environment $(31,32)$. Other authors report on parental communication in the context of substance use through the theory of planned behavior (TPB) that identifies subjective norms, personal attitudes, and perception of the behavior of others $(33,34)$.

In communication with their parents, peers directly transfer information while parents indirectly (knowledge of other parents, spouses, adolescents' brothers, and sisters) seek information on the friends of their adolescents. The opinions are conflicting on parents knowing the friends of their children and the influence peers have on their children.

The influence of peers is often indicated as the main reason why adolescents initiate negative behavior including tobacco, alcohol, and drug addiction $(35,36)$. Parents' directly and indirectly acquiring information on the place and type of activities of their adolescent children and their friends are important factors of potential influence on substance use (37). Although family communication provides numerous information, parents often do not ask questions, and adolescents often do not know whether their peers use substances $(38,39)$.

Although the sample of this study did not include parents, their attitudes and practice were analyzed through adolescents' statements. This was analyzed 
by other authors in the form of real parent attitudes about substance. They came to the conclusion that more strict parental attitudes are related to lower levels of substance use (40-43).

Hanewinkel et al. (44) conducted the first study of parental restriction of watching movies with inappropriate content (the media content of sensation seeking, smoking, and alcohol or violence) outside the USA and recommended the international model of supervision of adolescents. At the beginning, the prospective study included 2.110 German adolescents under the age of 15 who never smoke or drank alcohol. Following the parental restriction of watching the movies with the inappropriate content, 1 year later the same group of adolescents was tested for tobacco and alcohol use $(45,46)$. The results indicate that the restriction set for watching the mentioned movies most probably direct adolescents to other cable/satellite networks showing inappropriate content whereby parental restriction confirmed to have an independent function for adolescents $(47,48)$.

The German study (44) did not include media literacy $(49,50)$, but it did register that the attempts of smoking tobacco and drinking alcohol is widespread among German adolescents who later abuse these substances. The prevention of adolescents' problems requires family support with well-adapted communication. Many families face challenges while they attempt to provide the balance between family and business life, financial obligations, and provision of appropriate support and social contacts.

The factors such as the lack of trust and warmth in parent-child interaction, the lack of structure in family life, inappropriate practice in discipline and insufficient restrictions our expose adolescents to higher risks of substance abuse (51). Competent parenthood may protect children against various risky behaviors. Providing children with emotional and economic safety, control and appropriate restrictions are modeled (52-56) with the central position of the family in long-term prevention of risk of substance abuse. The studies indicate that authoritative parents who support and encourage their children to become independent, expect them to respect their rules, are consistent and just in their discipline practice, have the children that are more elastic than other children (57-60).
Spoth et al. (61) reported on the results of a study on accepting intervention partnership in the prevention of substance abuse among adolescents (in cities and villages) in 28 public schools in Pennsylvania over the period 2002-2008. They also refer to the results of the study conducted by Johnston et al. (62) that indicate increased prevalence in substance use among $10^{\text {th }}$-grade adolescents in 2008 (58.3\% consume alcohol, $31.7 \%$ use cigarettes, $29.9 \%$ marijuana, and $15.9 \%$ use illegal drugs). Both these and the follow-up studies point to the fact that the beginning of the partnership model delays serious substance use among adolescents while its development results in more efficient intervention in prevention $(63,64)$.

The support to the model for solving substance abuse is confirmed by the inclusion of community and intervention support network $(65,66)$, and Berwick (67) states that health-care systems are inefficient. That is why PROSPER, the community-university partnership model with evidence-based interventions coordinates the teamwork of all these participants as well as parents and schools (68). Early programs for family strengthening, through models of protection factors and parent network, may achieve results by the influence of community on addiction control (69-71). While continuous programs at schools through social and behavioral education and acceptance of the model for prevention of addiction have more intensive effects, the multidisciplinary model (PROSPER) of partnership provides long-term effects, but it requires financial and systemic national support in all environments.

Schwartz et al. (7) based their projections of study variables (acculturation trajectory $\rightarrow$ the functioning of family $\rightarrow$ problems in behavior) in the time period on the theoretical work of Szapocznik and Kurtines (72). A longitudinal study confirms the effects of the transition process influencing the functioning of a family as well as the outcome evident in adolescent behavior. The prediction of problems related to adolescents was made directly and indirectly through family functioning. Based on these studies, this paper aimed at testing the link between the structured model of functional communication and behavior in a family with the prevalence of tobacco, alcohol and drug use among the adolescents 
of the Tuzla Canton, in regard to the education level of parents and family structure.

The model of functional communication and behavior in a family includes family control and monitoring adolescents' free time; rules of behavior of adolescents at home and outside the home; family support (emotional, cognitive, social, and financial), and communication of prosocial family values (parents' attitudes about addiction). It is expected that the outcome of functional communication and behavior in a family is the lower prevalence in tobacco, alcohol, and drug usage among adolescents.

\section{METHODS}

\section{Subjects}

The study included randomly selected non-clinical sample of 1.018 adolescents (575 male and 443 female) of the Tuzla Canton (aged 17-19).

\section{Questionnaire}

The prospective method was used for anonymous examination of adolescents with the usage of the WHO instrument Youth Risk Behavior Surveillance System, modified for this study (73). The questionnaire included the information (variables) on every adolescent in two parts.

The first part of the questionnaire included the questions related to:

- Frequency (prevalence \%) of substance use (tobacco, alcohol, and drugs) coded as follows: $0=$ never $1=$ rarely $2=$ often, and the users with dual addition (tobacco and alcohol) coded by sex.

- For estimated consumption of tobacco and alcohol through the questions about the frequency of use: $0=$ never $1=$ rarely $2=$ often, while the answers to the usage of drugs were coded as $0=$ no and $1=$ yes.

- For the places where alcohol is consumed, coded as follows: $1=$ I have never drunk alcohol; $2=$ at home; $3=$ at someone else's home; $4=$ in the street, park; $5=$ at a café or bar; $6=$ at the disco; $7=$ at the restaurant.

The second part of the questionnaire refers to the evaluation of relationship with the parents and adolescents were asked to mark the following:
- Their family structure coded as: 1=complete family (father, mother, brother/sister); $2=$ expanded family (complete family + close relatives); $3=$ incomplete family (father or mother, brother/sister, close relatives); $4=$ household without family members.

- The level of parents' education coded as: $1=$ elementary school; 2=incomplete high school; $3=$ complete high school; $4=$ incomplete higher education; $5=$ higher education; $6=\mathrm{I}$ do not know.

- Adolescents' perception about the reaction of their parents to their use of substances, coded as: $1=$ They would not allow it; $2=\mathrm{I}$ do not know; $3=$ They did not approve of it; $4=\mathrm{I}$ do not have parents; 5: They approved of it; $6=$ They would not mind.

- Adolescents's satisfaction by the financial status in their family, coded as: $1=$ =very satisfied; $2=$ satisfied; $3=$ neutral; $4=$ not very satisfied; $5=$ dissatisfied.

- Communication in a family coded as: $0=$ often; $1=$ never; 2 =always/usually, in regard to the parents' rules and knowledge: $1=$ My parents set the rules about what I can do at home; $2=\mathrm{My}$ parents set the rules about what I can do outside home; 3=My parents know with whom I spend time in the evenings; $4=\mathrm{My}$ parents know where I am in the evenings; 5=I get support and attention from my parents.

\section{Statistical analysis}

The answers given by adolescents (coded variables) in the original questionnaires were systematized in MS Excel and then analyzed using the SPSS program (74). The mentioned variables in the SPSS program were processed using descriptive statistics (\% prevalence and participation) while the defined expectations were processed by quantitative statistical methods at the significance level $\mathrm{p}<0.05$, using Chi-square and t-test and one-way analysis of variance. The correlation of the tested variables was tested by the Pearson Correlation test, and all the data were presented in tables and Figures.

\section{RESULTS}

Adolescents of the Tuzla Canton on average $(81.2 \%)$ significantly more $(\mathrm{t}=66.35 ; \mathrm{p}<0.01)$ use the substances: Tobacco, alcohol, and drugs, when 
compared to those who do not use them (18.8\%). The average prevalence of frequent smoking tobacco is $33 \%$, frequent alcohol consumption $25.4 \%$, while $12 \%$ of them use drugs (the further analysis does not include drug users due to a small sample $\mathrm{n}=123, \mathrm{p}=0.32$ ). It is a warning sign that $41.3 \%$ of adolescents rarely use alcohol while the desire to try drugs was significantly registered $(\mathrm{F}[1.1]=324$; $\mathrm{p}<0.05$ ) by $84 \%$ of adolescents (Figure 1 ).

Some $31.8 \%$ of male adolescent subjects often use tobacco $(\mathrm{r}=0.117 ; \mathrm{p}<0.01)$ and $49.9 \%$ of them use alcohol $(\mathrm{r}=0.296 ; \mathrm{p}<0.01)$, when compared to female adolescents (Table 1). Both sexes of adolescents most often consume alcohol at someone else's home (28\%), at a café or bar (26\%), at home (20\%), and at the disco (16\%) (Table 2).

Complete and expanded family is significantly related $(\mathrm{p}<0.01)$ to the adolescent use of tobacco $(\mathrm{r}=0.45)$ and alcohol $(\mathrm{r}=0.14)$. There is an important correlation of tobacco use among adolescents coming from an incomplete family $(r=0.58$; $\mathrm{p}<0.01$ ) and from a household without family members $(r=0.42 ; p<0.05)$. The level of father's education does not influence $(r=0.06 ; \mathrm{p}=0.9)$, but a better father's education (high school or faculty) has a significant correlation with adolescent use of alcohol $(\mathrm{r}=0.14, \mathrm{p}<0.01)$. Mother's high school education has a significant correlation with adolescent use of tobacco $(\mathrm{r}=0.58, \mathrm{p}<0.01)$ and alcohol $(r=0.08, p<0.05)$. There is no significant difference registered in adolescent use of alcohol in relation to the financial status, while the adolescents "satisfied" with the financial status in their family register significant (Chi-square test $=19.7 ; \mathrm{p}<0.05)$ prevalence of smoking tobacco (Table 3).

As significantly perceived by adolescents, their parents would "not allow them to use substances" $(\mathrm{F}[2.439]=21.79 ; \mathrm{p}<0.01)$ while $14.5 \%$ of adolescents do not know how their parents would react (Figure 2). At the same time, parents are more strict $(\mathrm{F}=66.77$, df [2.3]; $\mathrm{p}<0.05)$ in setting the rules of behavior at home $(52.1 \%)$ than outside home $(45.5 \%)$. Adolescents claim that their parents know more $(\mathrm{F}=14.14$, df [2.6], $\mathrm{p}<0.05)$ about where $(82.5 \%)$ they spend their free time than with whom (78.6\%) (Figure 3).

\section{DISCUSSION}

The functioning of a family in the prevention of risk and use of substances (tobacco, alcohol, and drugs) was

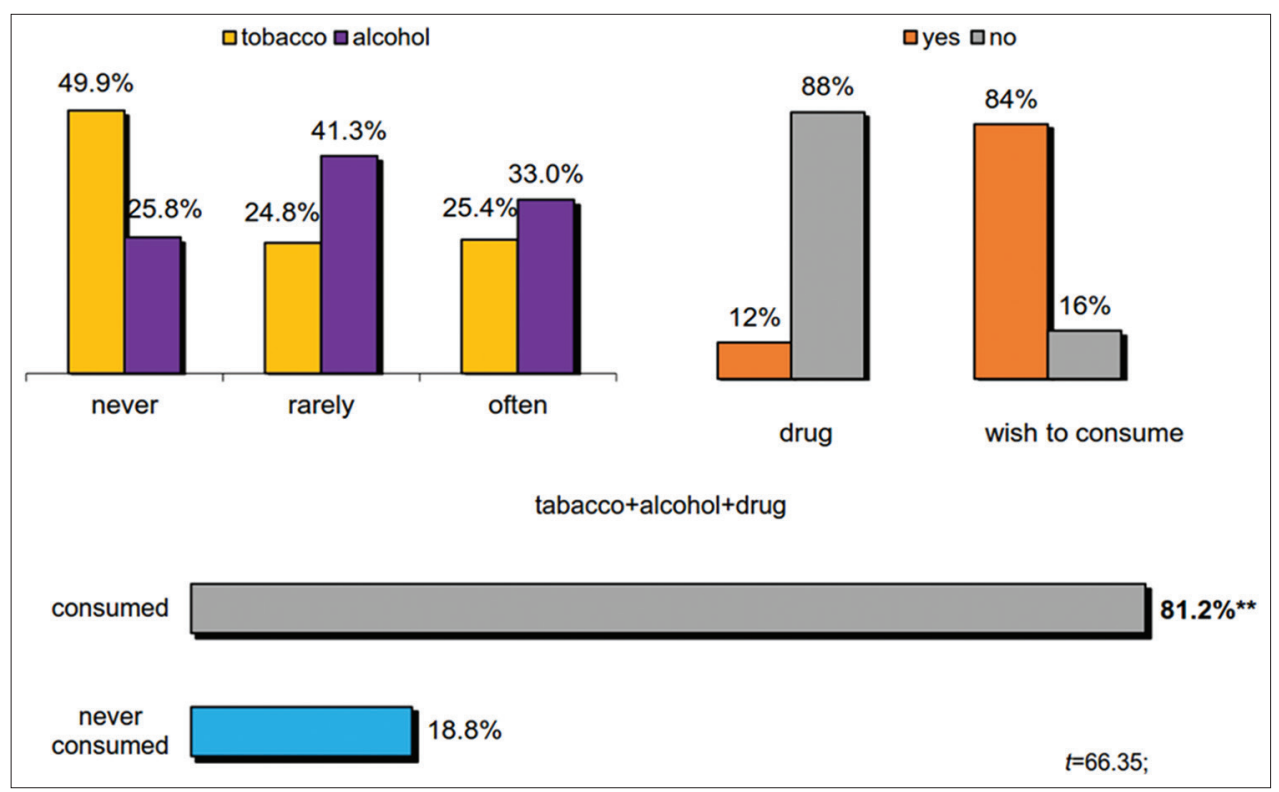

FIGURE 1. The prevalence of the consumption of tobacco, alchol, and drugs by adolescents. 


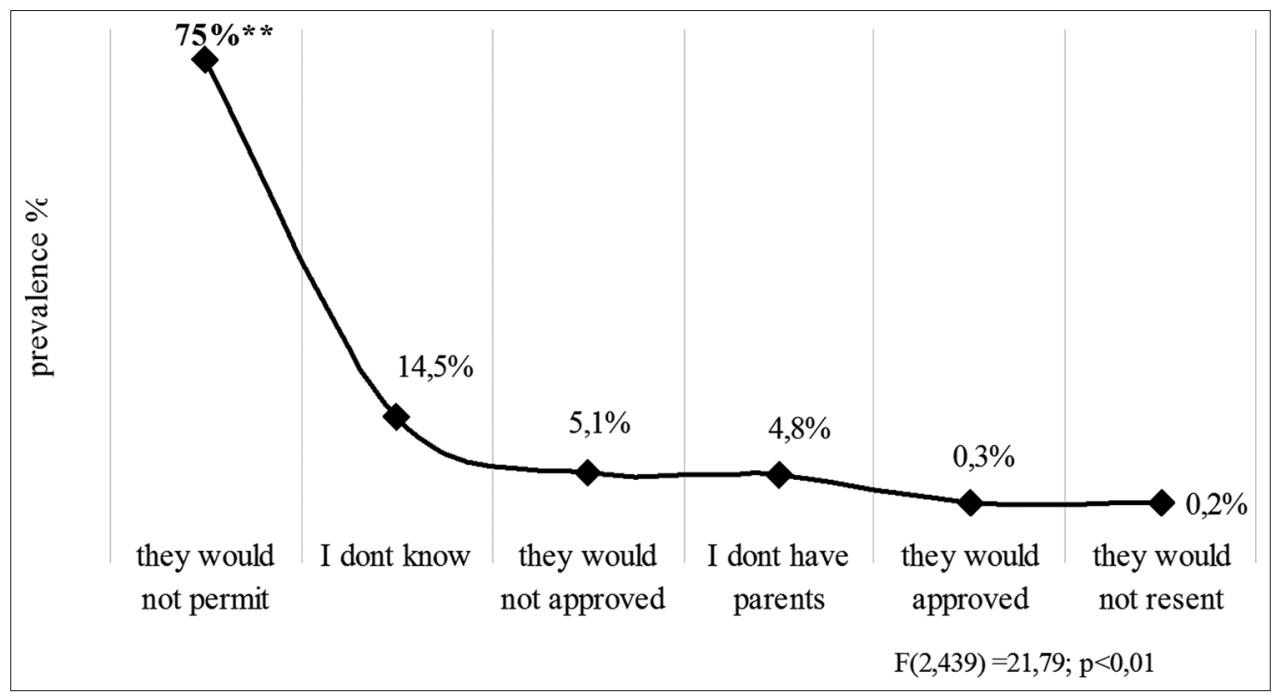

FIGURE 2. The adolescent's opinion on the parent's reactions toward substance use.

TABLE 1. The prevalence of tobacco and alcohol adolescents use by gender

\begin{tabular}{llccc}
\hline Addiction of & Consuming & \multicolumn{2}{c}{ Prevalence (\%) } & $r$ \\
\cline { 3 - 4 } & & Male & Female & \\
\hline Tobacco & Never & 45.4 & 53.3 & -0.117 \\
& Rarely & 21.7 & 27.8 & \\
& Often & $31.8^{*}$ & 19.0 & \\
Alcohol & Never & 19.8 & 31.8 & -0.296 \\
& Rarely & 30.3 & 52.2 & \\
& Often & $49.9^{*}$ & 16.0 & \\
\hline
\end{tabular}

${ }^{*} p<0.01, r=$ Pearson correlation

TABLE 2. The prevalence of alcohol use by location of consuming

\begin{tabular}{lcc}
\hline Location & $\mathrm{n}$ & Prevalence \% \\
\hline With someone else in the house & 203 & 28 \\
In a cafe or bar & 189 & 26 \\
At home & 145 & 20 \\
At disco & 115 & 16 \\
On the street, in the park & 51 & 7 \\
In other places & 31 & 4 \\
In a restaurant & 3 & 0 \\
Not consume alcohol & 281 & 38 \\
\hline
\end{tabular}

analyzed through the perception of 1,018 adolescents of the Tuzla Canton. The study aimed at the establishment of the family communication model as the prevalence of $81.2 \%$ is significant $(t=66.35 ; \mathrm{p}<0.01)$ in
TABLE 3. Family factors related to adolescents tobacco and alcohol use

\begin{tabular}{|c|c|c|}
\hline \multirow[t]{2}{*}{ Family factors } & \multicolumn{2}{|c|}{ Prevalence (\%) } \\
\hline & Tobacco & Alcohol \\
\hline \multicolumn{3}{|l|}{ The family structure } \\
\hline Complete family & $49.9^{* *}$ & $75.1^{* *}$ \\
\hline Extended family & $75^{\star \star}$ & $91.7^{\star *}$ \\
\hline Incomplete family & $50.2^{\star *}$ & 72.5 \\
\hline Household without of family members & $51.6^{*}$ & 74.2 \\
\hline \multicolumn{3}{|l|}{ Education level of father } \\
\hline Faculty education & 20.1 & 17.9 \\
\hline High school education & 69.8 & $70.4^{*}$ \\
\hline Elementary education & 12.6 & 8.8 \\
\hline \multicolumn{3}{|l|}{ Education level of mother } \\
\hline Faculty education & 9.5 & 9.4 \\
\hline High school education & $62.3^{*}$ & $62.9^{*}$ \\
\hline Elementary education & 25.7 & 25.7 \\
\hline \multicolumn{3}{|l|}{ Family financial status by adolescents } \\
\hline Very satisfied & 35.9 & 38.0 \\
\hline Satisfied & $44.5^{\mathrm{a}}$ & 45.6 \\
\hline Neutral & 12.6 & 9.3 \\
\hline Not very satisfied & 4.5 & 5.0 \\
\hline Not satisfied & 2.5 & 2.1 \\
\hline
\end{tabular}

defining the research problems. Other studies report on the evaluation of adolescent perception of their parents in the context of substance abuse $(16,17)$. 


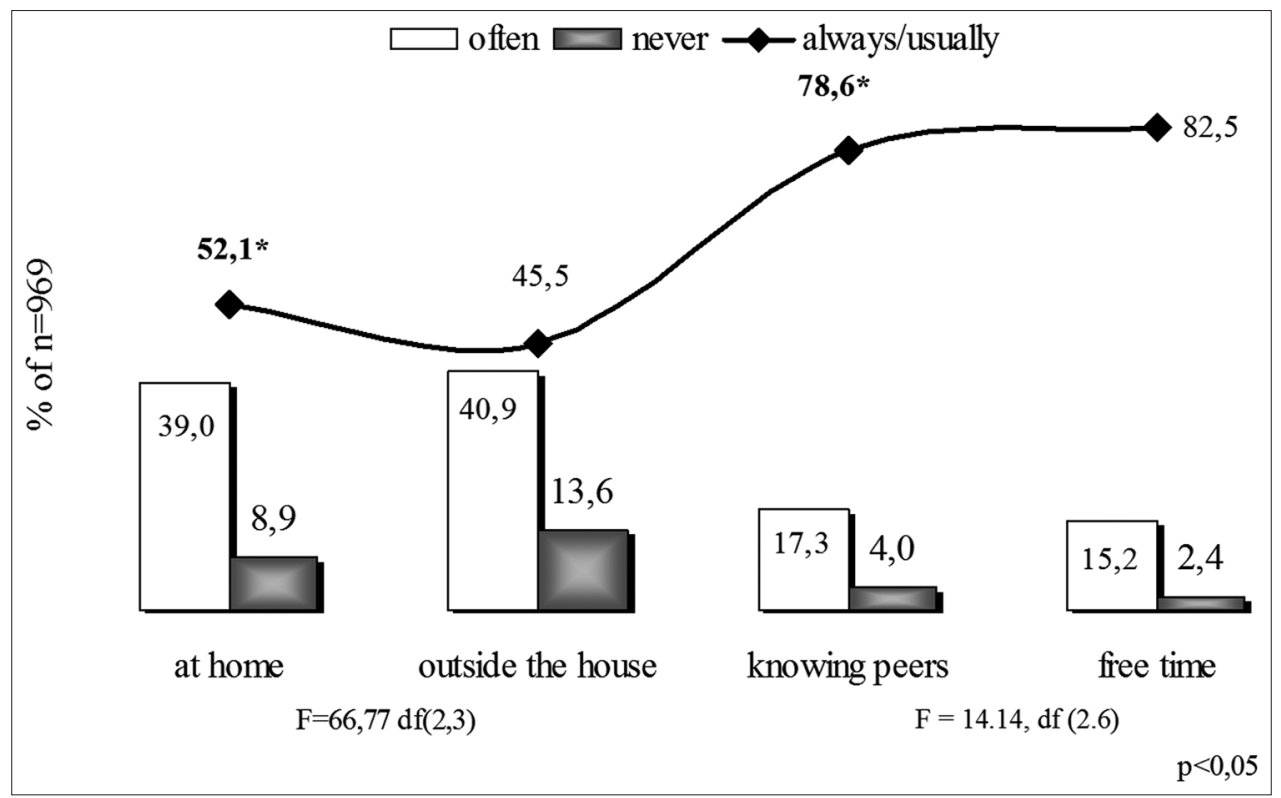

FIGURE 3. The perception of family rules and knowledge by adolescents.

As reported by the WHO, the prevalence of smoking in Bosnia and Herzegovina (75-77) is on the increase with $12.7 \%$ (2003), $13.3 \%$ (2008), and $15.5 \%$ (2013). The prevalence for adolescents smoking tobacco is $33 \%$ (frequently) and $24.8 \%$ (rarely) while Metzger et al. (78) reported the prevalence of tobacco use of $44 \%$, Abar et al. (79) state $5 \%$ prevalence for frequent and $8.4 \%$ prevalence for rare smoking tobacco among adolescents while Johnston et al. (80) in 5-year prevention measures report a drop in prevalence of smoking tobacco from $25 \%$ to $10 \%$. Edwards and Romero (81) suggested the strategies for smoking prevention through encouraging young people's self-esteem and their skills to face development problems. The increase in the prevalence of the use of tobacco and tobacco products among adolescents can be interpreted by development challenges imposed on them as well as by their taking over harmful behavior models. Stagnation in the prevention of tobacco and alcohol use in some countries can be interpreted as a result of education.

Although alcohol is frequently used by a quarter of adolescents, the problem is further complicated by $41.3 \%$ of those who rarely but still use alcohol. Some $31.8 \%$ of male adolescents consume tobacco $(\mathrm{r}=0.117 ; \mathrm{p}<0.01)$ and $49.9 \%$ of them consume alcohol $(\mathrm{r}=0.296 ; \mathrm{p}<0.01)$ which is more than female adolescents, which is reported by other authors as well (82).

Black et al. (83) used a non-clinical sample of 220 adolescents aged 12-18 the prevalence of alcohol use among female subjects (52.7\%) and among male subjects $(47.3 \%)$, with the prevalence of alcohol abuse among both sexes being $5.5 \%$ and the prevalence of alcohol addiction being $2.7 \%$. In this study, the adolescents of both sexes reported having consumed alcohol as follows: At someone else's home (28\%), at a café or a bar (26\%), at home $(20 \%)$, and at the disco (16\%). There is alarmingly high prevalence $(75 \%)$ of alcohol use registered among Dutch adolescents (84), Harford et al. (85) reported on the prevalence of alcohol use among US adolescents (aged 12-17) of $11.58 \%$ for male subjects and $11.02 \%$ for female subjects. While the prevalence of alcohol use among UK adolescents is $40.4 \%$ for male subjects and $42.4 \%$ for female subjects (86). In the primary health-care system, Levy et al. (87) used the NIAAA Youth alcohol screening tool and registered a third $(30.4 \%)$ of adolescents that consume alcohol, while there are significantly more male subjects who frequently consume alcohol $(6.9 \% ; \mathrm{p}<0.05)$ when compared to female subjects $(1.5 \%)$. 
Drug users ( $\mathrm{n}=123$ adolescents) register insignificant $(\mathrm{p}=0.32)$ average prevalence of $12 \%$, which is the reason they were not included in further analysis although there is significant $(F[1.1]=324 ; \mathrm{p}<0.05)$ desire to try drugs registered among $84 \%$ of adolescents. A similar methodological approach was used in the study conducted by Schwartz et al. (88) who surveyed adolescents about the frequency of smoking and drinking alcohol while drug usage was excluded from further analysis due to only nine subjects who reported the usage.

Other authors register frequent usage of legally sanctioned psychoactive substances among male adolescents $(89,90)$ and indicate that family plays a central role in strengthening or protecting against the risk of drug abuse. As perceived by adolescents, the functioning of a family is a protection factor for tobacco and alcohol use while parents' perception is registered in the domain of tobacco use only (88).

A higher frequency of tobacco use $(r=0.45 ; \mathrm{p}<0.01)$ and alcohol use $(\mathrm{r}=0.14 ; \mathrm{p}<0.01)$ correlates with adolescent complete and expanded family while incomplete family structure significantly increases the risk of smoking tobacco $(\mathrm{r}=0.58 ; \mathrm{p}<0.01)$ as well as the household without family members $(\mathrm{r}=0.42 ; \mathrm{p}<0.05)$. Other studies indicated higher frequency of drug and alcohol use among the adolescents with divorced parents and coming from the families with the mixed structure of parents and children $(91,92)$.

Due to the traditional roles of father and mother in child's upbringing, this study tested the individual levels of parent education. A higher level of father's education increased the risk of using alcohol $(\mathrm{r}=0.14, \mathrm{p}<0.01)$ but not tobacco smoking, unlike mother's education where an inverse proportion was registered for tobacco $(\mathrm{p}<0.01)$ and alcohol $(\mathrm{p}<0.05)$ use. Other studies provide methodological reports on the level of education of both parents, discussing their influence in regard to adolescent sex. Hence, a population cohort study conducted in Australia registered the prevalence of alcohol use among adolescents: $29 \%$ of male subjects and $38 \%$ of female subjects with parents who completed elementary school; $37 \%$ of male subjects and 33\% of female subjects with parents who completed high school, and 34\% of male subjects and $30 \%$ of female subjects with parents who completed higher education (93). Parents' expectations related to alcohol use depend on parents' education and they model the relationships between adolescents and family environment risk (94).

In this study, adolescents are satisfied with their financial status in a family $(\mathrm{p}<0.05)$, which indicates the lack of parental control and probable alienation of family members, while Eitle et al. (23) link the financial status to the factor of risk of alcohol addiction. Cano et al. (95) discovered the risks among adolescents related to multiple risks of family functioning (the basic function of a family and parental career in proportion to adolescents' risky behavior) and indicate the strategies of prevention activities aimed solely on parents.

As perceived by adolescents, parents have a negative attitude toward substance use, but they pay more attention to adolescent behavior at home. There is a statistical significance $(\mathrm{F}=14.14$, df [2.6], $\mathrm{p}<0.05)$ of parental control over where (but not with whom) adolescents spend their free time. This indicates that parents are familiar with the movement of their children, but they do not implement strictly set rules. Although this study did not include adolescents' peers, other studies point to peers (30-32) and indirect parental control over the environment of their adolescents (35-39). Cox et al. (96) also set the model of functioning of a family by which they studied the following: To what extent parents control school obligations of adolescents, where children spend their free time, to what extent parents know their children peers and parental attitudes about drug and alcohol use. The role of family function was confirmed (13-15) and in particular the role of father in alcohol use among adolescents. In that way, TPB identified the subjective norms of parents and children, their personal attitudes and perception about other people's behavior $(33,34)$.

Once established a negative pattern of behavior is difficult to change and later interventions are less successful. That is why the communication model of behavior in a family needs to include:

- Parental orientation to adolescents' free time,

- Setting the rules of behavior of adolescents at and outside home,

- Parental knowledge of their adolescents' environment, 
- Social and emotional support for adolescents and parents, and

- Encouragement of parental positive attitudes toward addiction (tobacco, alcohol, and drugs).

This study recognized the role of psychology and communication with adolescents, which Bruns et al. (97) named "wraparound" individualized team process of planning services and coordinating care aimed at improving the outcome among the youth with complex challenges regarding health and the behavior of their families. This would include philosophy, process and service toward strategically positive contribution of public health-care model in the national strategy of control, which is emphasized by recent preliminary studies (98).

\section{REFERENCES}

1. Cox R, Burr B, Blow A, Parra-Cardona JR. Latino adolescent substance use in the United states: Using the bioecodevelopmental model as an organizing framework. J Fam Theory Rev 2011;3:96-123

https://doi.org/10.1111/j.1756-2589.2011.00086.X.

2. Guilamo-Ramos V, Jaccard J, Dittus P, Bouris AM. Parental expertise, trustworthiness, and accessibility: Parent-adolescent communication and adolescent risk behavior. J Marriage Fam 2006;68(5):1229-46.

https://doi.org/10.1111/j.1741-3737.2006.00325.x.

3. Unger JB, Ritt-Olson A, Soto DW, Baezconde-Garbanati L. Parent-child acculturation discrepancies as a risk factor for substance use among Hispanic adolescents in Southern California. J Immigr Minor Health 2009;11(3):149-57.

https://doi.org/10.1007/s10903-007-9083-5

4. Perrino $\mathrm{T}$, Pantin $\mathrm{H}$, Huang S, Brincks $\mathrm{A}$, Brown $\mathrm{CH}$, Prado $\mathrm{G}$, et al. Reducing the risk of internalizing symptoms among high-risk Hispanic youth through a family intervention: A Randomized controlled trial. Fam Process 2016;55(1):91-106.

https://doi.org/10.1111/famp.12132.

5. Prado G, Pantin H. Reducing substance use and HIV health disparities among Hispanic youth in the USA: The familias unidas program of research. Psychosoc Interv 2011;20(1):63-73.

https://doi.org/10.5093/in2011v20n1a6.

6. Gil AG, Wagner EF, Vega WA. Acculturation, familism, and alcohol use among Latino adolescent males: Longitudinal relations. J Community Psychol 2000;28:443-58.

https://doi.org/10.1002/1520-6629(200007)28:4<443:AID-JCOP6>3.0.CO;2-A.

7. Schwartz SJ, Des Rosiers S, Huang S, Zamboanga BL, Unger JB, Knight GP, et al. Developmental trajectories of acculturation in Hispanic adolescents: Associations with family functioning and adolescent risk behavior. Child Dev 2013;84:1355-72.

https://doi.org/10.1111/cdev.12047.

8. Park S, Romer D. Problem behavior syndrome and its influence on the transition from experimental to daily smoking among adolescents in the U.S. J Addict Nurs 2010;21:114-22.

https://doi.org/10.3109/10884602.2010.481506.
9. Dillon FR, De La Rosa M, Schwartz SJ, Rojas P, Duan R, Malow RM, et al. US Latina age of sexual debut: Long-term associations and implications for HIV and drug abuse prevention. AIDS Care 2010;22(4):431-40.

https://doi.org/10.1080/09540120903202871.

10. LaBrie JW, Hummer JF, Lac A, Ehret PJ, Kenney SR. Parents know best, but are they accurate? Parental normative misperceptions and their relationship to students' alcohol-related outcomes. J Stud Alcohol Drugs 2011;72(4):521-9. https://doi.org/10.15288/jsad.2011.72.521.

11. Kandel DB, Andrews K. Processes of adolescent socialization by parents and peers. Int J Addict 1987;22(4):319-42. https://doi.org/10.3109/10826088709027433.

12. Wood MD, Read JP, Palfai TP, Stevenson JF. Social influence processes and college student drinking: The meditational role of alcohol outcome expectancies. J Stud Alcohol 2001;62(1):32-43.

https://doi.org/10.15288/jsa.2001.62.32.

13. Abar C, Turrisi R. How important are parents during the college years? A longitudinal perspective of indirect influences parents yield on their college teens alcohol use. Addict Behav 2008;33:1360-8.

https://doi.org/10.1016/j.addbeh.2008.06.010.

14. Turner AP, Larimer ME, Sarason IG. Family risk factors for alcohol-related consequences and poor adjustment in fraternity and sorority members: Exploring the role of parent-child conflict. J Stud Alcohol 2000;61:818-26.

https://doi.org/10.15288/jsa.2000.61.818.

15. Turrisi R, Ray AE. Sustained parenting and college drinking in first-year students. Dev Psychobiol 2010;52(3):286-94

https://doi.org/10.1002/dev.20434.

16. Szapocznik J, Scopetta MA, Kurtines WM, Aranalde MA. Theory and measurement of acculturation. Interam J Psychol 1978;12:113-30.

17. Schwartz SJ, Unger JB, Des Rosiers SE, Huang S, BaezcondeGarbanati L, Lorenzo-Blanco El, et al. Substance use and sexual behavior among recent Hispanic immigrant adolescents: Effects of parent-adolescent differential acculturation and communication. Drug Alcohol Depend 2012;125 Suppl 1:S26-34.

https://doi.org/10.1016/j.drugalcdep.2012.05.020.

18. Unger JB, Ritt-Olson A, Wagner KD, Soto DW, Baezconde-Garbanati L. Parent-child acculturation patterns and substance use among Hispanic adolescents: Alongitudinal analysis. J Prim Prev. 2009 Jul;30(3-4):293-313. https://doi: 10.1007/s10935-009-0178-8

19. Cano MÁ, Vaughan EL, de Dios MA, Castro Y, Roncancio AM, Ojeda L, et al. Alcohol use severity among Hispanic emerging adults in higher education: Understanding the effect of cultural congruity. Subst Use Misuse 2015;50(11):1412-20. https://doi.org/10.3109/10826084.2015.1018538.

20. Kulis S, Marsiglia FF, Nagoshi JL. Gender roles and substance use among Mexican American adolescents: A relationship moderated by acculturation? Subst Use Misuse 2012;47(3):214-29.

https://doi.org/10.3109/10826084.2011.630438.

21. Soto C, Unger JB, Ritt-OlsonA, Soto DW, BlackDS, Baezconde-Garbanati L, et al. Cultural values associated with substance use among Hispanic adolescents in southern California. Subst Use Misuse 2011;46:1223-33. https://doi.org/10.3109/10826084.2011.567366.

22. Unger JB, Shakib S, Gallaher P, Ritt-Olson A, Mouttapa M, Palmer PH, et al. Cultural/interpersonal values and smoking in an ethnically diverse sample of southern California adolescents. J Cult Divers 2006;13:55-63.

23. Eitle TM, Wahl AM, Aranda E. Immigrant generation, selective acculturation, and alcohol use among Latina/o adolescents. Soc Sci Res 2009;38:732-42.

https://doi.org/10.1016/j.ssresearch.2009.01.006. 
24. Lorenzo-Blanco El, Unger JB, Baezconde-Garbanati L, Ritt-Olson A, Soto D. Acculturation, enculturation, and symptoms of depression in Hispanic youth: The roles of gender, Hispanic cultural values, and family functioning. J Youth Adolesc 2012;41(10):1350-65. https://doi.org/10.1007/s10964-012-9774-7.

25. La Framboise T, Rowe W. Skills training for bicultural competence: Rationale and application. J Couns Psychol 1983;30:589-95. https://doi.org/10.1037/0022-0167.30.4.589.

26. Lorenzo-Blanco El, Unger JB, Ritt-Olson A, Soto D, Baezconde-Garbanati L. Acculturation, gender, depression, and cigarette smoking among U.S. Hispanic youth: The mediating role of perceived discrimination. J Youth Adolesc 2011;40(11):1519-33. https://doi.org/10.1007/s10964-011-9633-y.

27. Lorenzo-Blanco El, Unger JB, Oshri A, Baezconde-Garbanati L, Soto D. Profiles of bullying victimization, discrimination, social support, and school safety: Links with Latino/a youth acculturation, gender, depressive symptoms, and cigarette use. Am J Orthopsychiatry 2016;86(1):37-48. https://doi.org/10.1037/ort0000113.

28. Hurtado A. Multiple lenses: Multicultral feminist theory. In: Landrine $\mathrm{H}$, Felipe Russo N, editors. Handbook of Diversity in Feminist Psychology. New York: Springer; 2010. p. 29-54.

29. Roberts TK, Eugenin EA, Lopez L, Romero IA, Weksler BB, Couraud PO, et al. $\mathrm{CCL}_{2}$ disrupts the Adherens junction: Implications for neuroinflammation. Lab Invest 2012;92(8):1213-33.

https://doi.org/10.1038/labinvest.2012.80

30. Wood MD, Read JP, Mitchell RE, Brand NH. Do parents still matter? Parent and peer influences on alcohol involvement among recent high school graduates. Psychol Addict Behav 2004;18(1):19-30.

https://doi.org/10.1037/0893-164X.18.1.19.

31. Grimes CL, Klein TR, Putallaz M. Parents' relationships with their parents and peers: Influences on children's social development. In: Kupersmidt JB, Dodge K, editors. Children's Peer Relations: From Development to Intervention. Washington, DC: American Psychological Association; 2004. p. 141-58.

https://doi.org/10.1037/10653-008.

32. King KA, Wagner DI, Hedrick B. Parents reported needs in preventing their children from engaging in alcohol, tobacco, and other drug use. Am J Health Educ 2002;33:70-6. https://doi.org/10.1080/19325037.2002.10609419.

33. Conner M, Warren R, Close S, Sparks P. Alcohol consumption and the theory of planned behavior: An examination of the cognitive mediation of past behavior. J Appl Soc Psychol 1999;29:1676-704

https://doi.org/10.1111/j.1559-1816.1999.tb02046.x.

34. Norman $P$, Conner M. The theory of planned behaviour and binge drinking: Assessing the moderating role of past behaviour within the theory of planned behaviour. Br J Health Psychol 2006;11:55-70.

https://doi.org/10.1348/135910705X43741.

35. Kumpfer KL, Alvarado R, Whiteside HO. Family-based interventions for substance use and misuse prevention. Subst Use Misuse 2003;38:1759-87. https://doi.org/10.1081/JA-120024240.

36. Gardner F, Burton J, Klimes I. Randomised controlled trial of a parenting intervention in the voluntary sector for reducing child conduct problems: Outcomes and mechanisms of change. J Child Psychol Psychiatry 2006;47:1123-32.

https://doi.org/10.1111/j.1469-7610.2006.01668.x.

37. Bourdeau B, Miller BA, Duke MR, Ames GM. Parental strategies for knowledge of adolescents' friends: Distinct from monitoring? J Child Fam Stud 2011;20:814-21.

https://doi.org/10.1007/s10826-011-9449-0.
38. Crouter AC, Bumpus MF, Davis KD, McHale SM. How do parents learn about adolescents' experiences? Implications for parental knowledge and adolescent risky behavior. Child Dev 2005;76:869-82.

https://doi.org/10.1111/j.1467-8624.2005.00883.x.

39. Belendiuk KA, Molina BS, Donovan JE. Concordance of adolescent reports of friend alcohol use, smoking, and deviant behavior as predicted by quality of relationship and demographic variables (JSAD 71: 253). J Stud Alcohol Drug 2010;71:253.

https://doi.org/10.15288/jsad.2010.71.253

40. Wilks J, Callan VJ, Austin DA. Parent, peer and personal determinants of adolescent drinking. Br J Addict 1989;84:619-30.

https://doi.org/10.1111/j.1360-0443.1989.tb03477.x.

41. Oostveen T, Knibbe R, de Vries H. Social influences on young adults' alcohol consumption: Norms, modeling, pressure, socializing, and conformity. Addict Behav 1996;21(2):187-97.

https://doi.org/10.1016/0306-4603(95)00052-6.

42. Brody GH, Ge X, Katz J, Arias IA. Longitudinal analysis of internalization of parental alcohol-use norms and adolescent alcohol use. Appl Dev Sci 2000;4:71-9. https://doi.org/10.1207/S1532480XADS0402_2.

43. van der Vorst $H$, Engels RC, Meeus W, Deković M. The impact of alcohol-specific rules, parental norms about early drinking and parental alcohol use on adolescents' drinking behavior. J Child Psychol Psychiatry 2006;47(12):1299-306.

https://doi.org/10.1111/j.1469-7610.2006.01680.x

44. Hanewinkel R, Morgenstern M, Tanski SE, Sargent JD. Longitudinal study of parental movie restriction on teen smoking and drinking in Germany. Addiction 2008:103:1722-30. https://doi.org/10.1111/j.1360-0443.2008.02308.x.

45. Dalton MA, Tickle JJ, Sargent JD, Beach ML, Ahrens MB, Heatherton TF et al. The incidence and context of tobacco use in popular movies from 1988 to 1997 . Prev Med 2002;34:516-23.

https://doi.org/10.1006/pmed.2002.1013.

46. Sargent JD, Wills TA, Stoolmiller M, Gibson J, Gibbons FX. Alcohol use in motion pictures and its relation with early-onset teen drinking. J Stud Alcohol 2006;67(1):54-65. https://doi.org/10.15288/jsa.2006.67.54

47. Sargent JD, Dalton MA, Heatherton T, Beach M. Modifying exposure to smoking depicted in movies: A novel approach to preventing adolescent smoking. Arch Pediatr Adolesc Med 2003;157(7):643-8.

https://doi.org/10.1001/archpedi.157.7.643.

48. Sargent JD, Beach ML, Dalton MA, Ernstoff LT, Gibson JJ, Tickle JJ, et al. Effect of parental R-rated movie restriction on adolescent smoking initiation: A prospective study. Pediatrics 2004;114:149-56

https://doi.org/10.1542/peds.114.1.149

49. Brown JD. Media literacy has potential to improve adolescents' health J Adolesc Health 2006;39(4):459-60.

https://doi.org/10.1016/j.jadohealth.2006.07.014

50. Primack BA, Gold MA, Switzer GE, Hobbs R, Land SR, Fine MJ, et al. Development and validation of a smoking media literacy scale for adolescents. Arch Pediatr Adolesc Med 2006;160(4):369-74.

https://doi.org/10.1001/archpedi.160.4.369.

51. Parke RD. Development in the family. Annu Rev Psychol 2004:55:365-99. https://doi.org/10.1146/annurev.psych.55.090902.141528.

52. Maccoby E, Martin J. Socialization in the context of the family: Parent-child interaction. In: Mussen P, Hetherington EM, editors Handbook of Child Psychology: Socialization, Personality and Social Development. $4^{\text {th }}$ ed. New York: John Wiley and Sons; 1983. p. 1-101. 
53. Dishion TJ, Andrews DW, Crosby L. Antisocial boys and their friends in early adolescence: Relationship characteristics, quality, and interactional process. Child Dev 1995;66(1):139-51.

https://doi.org/10.2307/1131196.

54. Jones D. The assessment of parental capacity. In: Horwath J, editor. The Child's World: Assessing Children in Need. London: Jessica Kingsley; 2001. p. 255-72.

55. van der Vorst H, Engels RC, Meeus W, Dekovic M. Parental attachment, parental control, and early development of alcohol use: A longitudinal study. Psychol Addict Behav 2006;20(2):107-16.

https://doi.org/10.1037/0893-164X.20.2.107.

56. Van Der Vorst H, Engels RC, Deković M, Meeus W, Vermulst AA. Alcoholspecific rules, personality and adolescents' alcohol use: A longitudinal person-environment study. Addiction 2007;102(7):1064-75.

https://doi.org/10.1111/j.1360-0443.2007.01855.x.

57. Stephenson MT, Helme DW. Authoritative parenting and sensation seeking as predictors of adolescent cigarette and marijuana use. J Drug Educ 2006;36(3):247-70.

https://doi.org/10.2190/Y223-2623-7716-2235.

58. Stephenson MT, Quick BL, Atkinson J, Tschida DA. Authoritative parenting and drug-prevention practices: Implications for antidrug ads for parents. Health Commun 2005;17(3):301-21.

https://doi.org/10.1207/s15327027hc1703_6.

59. Walsh F. Family resilience: A framework for clinical practice. Fam Process 2003;42(1):1-8.

https://doi.org/10.1111/j.1545-5300.2003.00001.x.

60. Olson DH, Gorall DM. Circumplex model of marital and family systems. In: Walsh F, editor. Normal Family Processes: Growing Diversity and Complexity. $3^{\text {rd }}$ ed. New York: Guilford Press; 2003. p. 514-47. https://doi.org/10.4324/9780203428436_chapter_19.

61. Spoth R, Redmond C, Clair S, Shin CH, Greenberg M, Feinberg M. Preventing substance misuse through community-university partnerships: Randomized controlled trial outcomes $4 \frac{1}{2}$ years past baseline. Am J Prev Med 2011;40(4):440-7.

https://doi.org/10.1016/j.amepre.2010.12.012.

62. Johnston LD, O'Malley PM, Bachman JG, Schulenberg JE. Monitoring the Future National Results on Adolescent Drug Use: Overview of Key Findings, 2008. (NIH Publication 09-7401). Bethesda, MD: National Institute on Drug Abuse, USDHHS; 2008.

63. Spoth R, Guyll M, Shin C. Universal intervention as a protective shield against exposure to substance use: Long-term outcomes and public health significance. Am J Public Health 2009;99:2026-33.

https://doi.org/10.2105/AJPH.2007.133298.

64. Spoth RL, Trudeau L, Guyll M, Shin C, Redmond C. Universal intervention effects on substance use among young adults mediated by delayed adolescent substance initiation. J Consult Clin Psychol 2009;77:620-32. https://doi.org/10.1037/a0016029.

65. Spoth RL, Greenberg MT. Toward a comprehensive strategy for effective practitioner-scientist partnerships and larger-scale community benefits. Am J Community Psychol 2005;35:107-26.

https://doi.org/10.1007/s10464-005-3388-0.

66. Grumbach K, Mold JW. A health care cooperative extension service: Transforming primary care and community health. JAMA 2009;301(24):2589-91.

https://doi.org/10.1001/jama.2009.923.

67. Berwick DM. Disseminating innovations in health care. JAMA 2003;289(15):1969-75.

https://doi.org/10.1001/jama.289.15.1969.

68. Spoth R, Greenberg MT, Bierman K, Redmond C. PROSPER community-university partnerships model for public education systems: Capacity-building for evidence-based, competence-building prevention [Invited article for Special issue]. Prev Sci 2004;5(1):31-9.

https://doi.org/10.1023/B: PREV.0000013979.52796.8b.

69. Molgaard VM, Kumpfer K, Fleming E. Strengthening Families Program for Parents and Youth 10-14: A Video-Based Curriculum. Ames, IA: Institute for Social and Behavioral Research; 1997.

70. Spoth R, Redmond C, Shin C, Greenberg M, Clair S, Feinberg M. Substance use outcomes at 18 months past baseline: The PROSPER community-university partnership trial. Am J Prev Med 2007;32(5):395-402. https://doi.org/10.1016/j.amepre.2007.01.014.

71. Spoth R, Clair S, Greenberg M, Redmond C, Shin C. Toward dissemination of evidence-based family interventions: Maintenance of community-based partnership recruitment results and associated factors. J Fam Psychol 2007;21(2):137-46.

https://doi.org/10.1037/0893-3200.21.2.137.

72. Szapocznik J, Kurtines WM. Family psychology and cultural diversity: Opportunities for theory, research, and application. Am Psychol 1993;48:400-7. https://doi.org/10.1037/0003-066X.48.4.400.

73. The World Health Organization (WHO). Youth Risk Behavior Surveillance System (YRBSS). World Health Organization; 2016 [cited 6 April 2017]. Available from: http://www.cdc.gov/yrbss.

74. Pallant J. SPSS: Priručnik za Preživljavanje. Beograd: Mikro knjiga; 2007.

75. The World Health Organization (WHO). Global Youth Tabacco Survey (GYTS). World Health Organization; 2003 [cited 13 April 2017]. Available from: http://www.cdc.gov/yrbss.

76. The World Health Organization (WHO). Global Youth Tabacco Survey (GYTS). World Health Organization; 2008 [cited 13 April 2017]. Available from: http://www.cdc.gov/yrbss.

77. The World Health Organization (WHO). Global Youth Tabacco Survey (GYTS). World Health Organization; 2013 [cited 13 April 2017]. Available from: http://www.cdc.gov/yrbss.

78. Metzger A, Wakschlag LS, Anderson R, Darfler A, Price J, Flores Z, et al. Information management strategies within conversations about cigarette smoking: Parenting correlates and longitudinal associations with teen smoking. Dev Psychol 2013;49(8):1565-78.

https://doi.org/10.1037/a0030720.

79. Abar CC, Jackson KM, Colby SM, Barnett NP. Common and unique parenting predictors of adolescent tobacco and alcohol use. Addict Behav 2014;39(10):1528-32.

https://doi.org/10.1016/j.addbeh.2014.06.003.

80. Johnston LD, O'Malley PM, Bachman JG, Schulenberg JE. Monitoring the Future National Survey Results on Adolescent Drug Use: Overview of Key Findings, 2012. Ann Arbor: Institute for Social Research, The University of Michigan; 2013.

81. Edwards LM, Romero AJ. Coping with discrimination among Mexican descent adolescents. Hisp J Behav Sci 2008;30(1):24-39.

https://doi.org/10.1177/0739986307311431.

82. Hibell B, Guttormsson U, Ahlström S, Balakireva O, Bjarnason T, Kokkevi A, et al. The 2011 ESPAD Report: Substance use among students in 36 European countries. Stockholm: The Swedish Council for Information on Alcohol and Other Drugs (CAN); 2012.

83. Black JJ, Clark DB, Martin CS, Kim KH, Blaze TJ, Creswell KG, et al. Course of alcohol symptoms and social anxiety disorder from adolescence to young adulthood. Alcohol Clin Exp Res 2015;39(6):1008-15.

https://doi.org/10.1111/acer.12711.

84. van der Zwaluw CS, Scholte RH, Vermulst AA, Buitelaar JK, Verkes RJ, Engels RC, et al. Parental problem drinking, parenting, and adolescent alcohol use. J Behav Med 2008;31:189-200.

https://doi.org/10.1007/s10865-007-9146-z. 
85. Harford TC, Yi HY, Faden VB, Chen CM. The dimensionality of DSM-IV alcohol use disorders among adolescent and adult drinkers and symptom patterns by age, gender, and race/ethnicity. Alcohol Clin Exp Res 2009;33:868-78

https://doi.org/10.1111/j.1530-0277.2009.00910.x.

86. Morleo M, Cook PA, Elliott G, Phillips-Howard PA. Parental knowledge of alcohol consumption: A cross sectional survey of 11-17 year old schoolchildren and their parents. BMC Public Health 2013;13:412-22.

https://doi.org/10.1186/1471-2458-13-412.

87. Levy S, Dedeoglu F, Gaffin JM, Garvey KC, Harstad E, MacGinnitie A, et al. A screening tool for assessing alcohol use risk among medically vulnerable youth. PLoS One 2016;11(5):e0156240.

https://doi.org/10.1371/journal.pone.0156240.

88. Schwartz SJ, Unger JB, Des Rosiers SE, Lorenzo-Blanco El, Zamboanga BL, Huang S, et al. Domains of acculturation and their effects on substance use and sexual behavior in recent Hispanic immigrant adolescents. Prev Sci 2014;15:385-96.

https://doi.org/10.1007/s11121-013-0419-1.

89. Chassin L, Hussong A, Barrera M Jr., Molina BS, Trim R, Ritter J. Adolescent substance use. In: Lerner RM, Steinberg L, editors. Handbook of Adolescent Psychology. $2^{\text {nd }}$ ed. Hoboken, New Jersey: John Wiley \& Sons, Inc.; 2004. p. 665-96. https://doi.org/10.1002/9780471726746.ch21.

90. Hibell B, Guttormsson U, Ahlström S, Balakireva O, Bjarnason T, Kokkevi A, et al. The 2007 ESPAD Report: Substance use Among Students in 35 European Countries. Stockholm: The Swedish Council for Information on Alcohol and Other Drugs (CAN); 2009.

91. Hoffmann PJ, Johnson RA. A national portrait of family structure and adolescent drug use. J Marriage Fam 1998;60:633-45. https://doi.org/10.2307/353534.

92. Hemovich V, Crano WD. Family structure and adolescent drug use: An exploration of single-parent families. Subst Use Misuse 2009;44:2099-113 https://doi.org/10.3109/10826080902858375.

93. Olsson CA, Romaniuk H, Salinger J, Staiger PK, Bonomo Y, Hulbert C, et al. Drinking patterns of adolescents who develop alcohol use disorders: Results from the victorian adolescent health cohort study. BMJ Open 2016;6(2):e010455.

https://doi.org/10.1136/bmjopen-2015-010455.

94. McQueen N. Pathways to adolescent alcohol use: Family environment, peer influence, and parental expectations. J Adolesc Health 2005;37(1):19-28.

https://doi.org/10.1016/j.jadohealth.2004.06.004.

95. Cano MA, Schwartz SJ, Castillo LG, Unger JB, Huang S, Zamboanga BL, et al. Health risk behaviors and depressive symptoms among Hispanic adolescents: Examining acculturation discrepancies and family functioning. J Fam Psychol 2016;30(2):254-65.

https://doi.org/10.1037/fam0000142.

96. Cox RB, Roblyer MZ, Merten MJ, Shreffler KM, Schwerdtfeger KL. Do parent-child acculturation gaps affect early adolescent Latino alcohol use? A study of the probability and extent of use. Subst Abuse Treat Prev Policy 2013;8(4):1-13.

https://doi.org/10.1186/1747-597X-8-4.

97. Bruns EJ, Walker JS, Zabel M, Matarese M, Estep K, Harburger D, et al. Intervening in the lives of youth with complex behavioral health challenges and their families: The role of the wraparound process. Am J Community Psychol 2010;46:314-31.

https://doi.org/10.1007/s10464-010-9346-5.

98. Walker JS, Bernstein A, Daleiden E, Pullmann MD, Chorpita BF. Family voice with informed choice: Coordinating wraparound with research-based treatment for children and adolescents university of Washington. J Clin Child Adolesc Psychol 2014;43(2):256-69.

https://doi.org/10.1080/15374416.2013.859081. 